\title{
Water Related Health Problems in Central Asia-A Review
}

\author{
Zakir Bekturganov ${ }^{1}$, Kamshat Tussupova ${ }^{2}$, Ronny Berndtsson ${ }^{2,}{ }^{*}$, Nagima Sharapatova ${ }^{3}$, \\ Kapar Aryngazin ${ }^{4}$ and Maral Zhanasova ${ }^{5}$ \\ 1 Department of Public Health, Karaganda State Medical University, Gogol Street 40, Karaganda 100008, \\ Kazakhstan; bekturganov@kgmu.kz \\ 2 Department of Water Resources Engineering \& Center for Middle Eastern Studies, Lund University, Box 118, \\ Lund SE-221 00, Sweden; kamshat.tussupova@tvrl.lth.se \\ 3 MROO “Educational-health Center", Petrova str. 30/1, 13, Astana 010000, Kazakhstan; \\ nagima.sharapatova@gmail.com \\ 4 Department of Professional Training and Protection of the Environment, Pavlodar State University, \\ Lomov Street 64, Pavlodar 140008, Kazakhstan; kapar47@mail.ru \\ 5 Department of Surgical Disease, Karaganda State Medical University, Gogol Street 40, Karaganda 100008, \\ Kazakhstan; maral_8208@mail.ru \\ * Correspondence: ronny.berndtsson@tvrl.lth.se; Tel.: +46-46-222-8986 \\ Academic Editor: Marc Henry \\ Received: 17 February 2016; Accepted: 20 May 2016; Published: 24 May 2016
}

\begin{abstract}
The present paper provides an extensive literature review on water related health issues in Central Asia. Even though the per capita amount of available freshwater is substantial in all Central Asian states the uneven distribution in time and space creates problems for water availability. Due to this, the Central Asian economies are developing under increasing water deficiency. The degradation of water supply systems and sewage treatment plants is often severe leading to potentially high water loss rates and inadequate accessibility to safe water supply. In this context, rural areas are the most affected. Low tariffs in combination with absent metering and low collection rates for water fees mean that operation and maintenance costs for basic services of water supply and sanitation are not covered. Unsafe water supply contains both microbiological and non-microbiological contaminants. Helminthiasis and intestinal protozoa infections are of considerable public health importance in Central Asia. Agricultural and industrial pollution is especially affecting downstream areas of Amu Darya and Syr Darya rivers. In large areas copper, zinc, and chromium concentrations in water exceed maximum permissible concentration. Thus, there is an urgent need to strengthen the environmental monitoring system. Small-scale water supply and sanitation systems need to be developed in line with more efficient public spending on these.
\end{abstract}

Keywords: Central Asia; water supply; public health; safe drinking water; sanitation; pollution

\section{Introduction}

Central Asia refers to the five former Soviet Union states Kazakhstan, Turkmenistan, Uzbekistan, Tajikistan, and Kyrgyzstan [1]. Central Asia stretches from the Caspian Sea in the west to China in the east and from Afghanistan in the south to Russia in the north (Figure 1). 


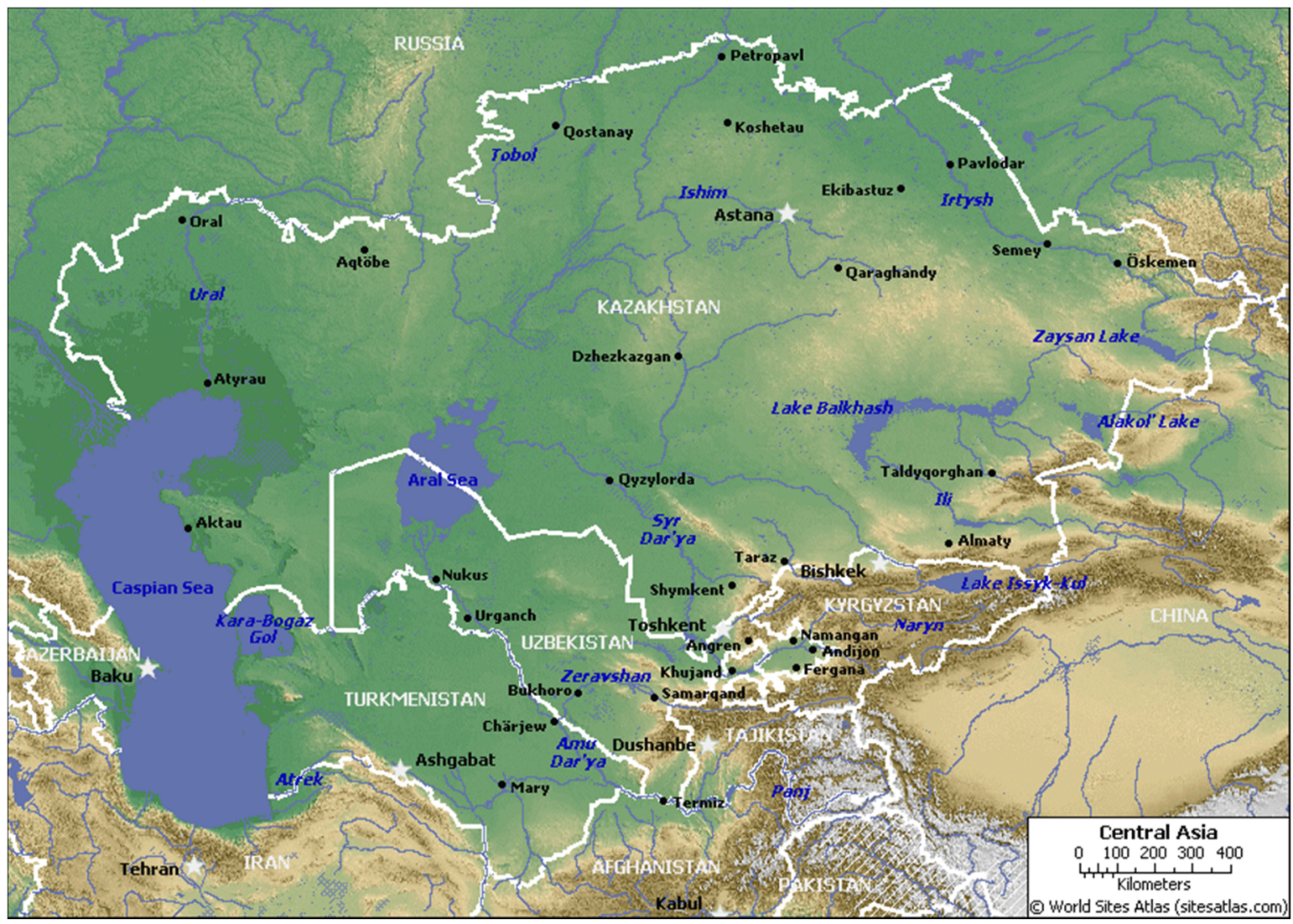

Figure 1. Outline of Central Asia and the five former Soviet Union states Kazakhstan, Turkmenistan, Uzbekistan, Tajikistan, and Kyrgyzstan (courtesy of World Sites Atlas).

Consequently, all five Central Asian states have experienced the crumbling of the Soviet Union in 1991, the following collapse of the economic system, and the subsequent socioeconomic upheaval [2]. The transition from state planned to market economy has meant changing patterns for basic services such as water supply and sanitation [3]. At present Central Asia is home to a population of about 66 million (Kazakhstan 17.0 million, Kyrgyzstan 5.7 million, Tajikistan 8.0 million, Turkmenistan 5.2 million, and Uzbekistan 30.0 million) [4]. By 2040, the total population is expected to have increased to about 86 million. This together with countryside migration to urban areas will put an enormous stress on water and infrastructure. Water supply availability in Central Asia is complicated due to that the region's two major rivers, the Syr Darya and Amu Darya, are transboundary. Thus, continual conflicts over the region's water resources have characterized the Central Asian states since the collapse of the Soviet Union [4].

The Central Asian economies are developing under increasing water deficiency [5-9]. According to I.V. Severskiy [2], 70\% of developmental problems in the region are caused by freshwater shortage. The main reasons for this are increasing political tensions and worsening ecological and socioeconomic conditions. Freshwater shortage, however, also affects the public health and providing continuous access to safe drinking water is fundamental to protecting the population from microbiological disease [10]. Before 1991, public health service mainly followed the Soviet model with priority on regulatory hygienic and sanitary control measures for combatting infectious diseases [11]. After 1991, the notion of "New Public Health" including a broader range of evidence-based scientific, technological, and management based systems for improving the health of individuals became more widely accepted [12-14]. The new approach, that also stressed chronic non-communicable diseases, health policy, health promotion, health systems management, and public health practice, eventually lead forward to the reformulation of educational programmes and legislation. At present the main challenge for Central Asian states public health sectors is in clarifying, coordinating, and streamlining the 
roles and responsibilities of different agencies responsible for public health and health promotion activities [15].

In view of the above, there is a remarkable absence of basic information on water related health issues of Central Asia in the English scientific literature. The lack of information may reflect a general absence of investigation efforts during the period following the collapse of the Soviet Union. It is believed that this collapse also was followed by a breakdown in public health infrastructure. On the other hand, much of this information may be delimited to the Russian scientific literature. Relevant data and information may also be available in unpublished documents and reports. The authors are, however, not aware of any previous scientific publication trying to cover the state of art situation on water related health problems in the Central Asia. Along this line, we try to summarize all available scientific literature and publically available reports on this subject, synthesise, and draw general conclusion from the state of water and health in Central Asia. The introductory chapter is followed by a description of distribution of freshwater resources of Central Asia. The chapter after this describes threats to water quality. In the following chapter, access to safe water is outlined. The final chapter treats occurring and possible future health impacts. We close with a conclusion and a discussion on possible ways forward.

\section{Distribution of Freshwater Resources}

Central Asia is located in the centre of the Eurasian continent occupying an area of about 4 million $\mathrm{km}^{2}$ [16]. The main part of the Central Asia is arid and thus, there is a general deficit of freshwater. The climate is strongly continental arid to semiarid with hot cloud-free summers and humid temperate winters in the south and cold winters in the north [17]. Average annual precipitation for Central Asia is about $273 \mathrm{~mm}$. It varies from about $161 \mathrm{~mm}$ in Turkmenistan to $691 \mathrm{~mm}$ per year in Tajikistan. The by far largest country Kazakhstan receives on average about $250 \mathrm{~mm}$ per year. The plains and deserts receive less than $70 \mathrm{~mm}$ per year and the high mountains of central Tajikistan up to $2400 \mathrm{~mm}$ per year [18-22]. Potential evaporation similarly varies from above $2250 \mathrm{~mm}$ per year in the most arid region to less than $500 \mathrm{~mm}$ per year in the mountainous areas.

Water resources in Central Asia are constituted by surface water and groundwater. The major part of potentially usable water comes from the large rivers of the region. All these rivers, however, are transboundary. The largest, the Amu Darya and the Syr Darya, flow through more than three countries. The Amu Darya and Syr Darya account for 90\% of Central Asia's river water. Especially, Turkmenistan and Uzbekistan are vulnerable due to that a major part of the water resources is generated outside of their respective territory. The Central Asian water problem is thus, complex and also involving other transboundary stakeholders such as Russia, China, Afghanistan, Iran, and Pakistan. Other large rivers are the Irtysh and Ishym located in the east parts of Central Asia, the Chu and Talas located in the south, in the west the Ural can be found, and finally the Ishim and Tobol are found in the north [2]. The by far largest withdrawal of water for irrigation is done from the large rivers of the region. However, the area also contains countless smaller river and creeks that as well contribute to irrigated agriculture. The information on this, however, is often absent.

Totally available water resources the respective country are given in Table 1 [23-25]. The groundwater resources generally constitute about $10 \%-15 \%$ in comparison to the surface water resources [23]. Turkmenistan, though, has reminiscent groundwater only. As seen from the table, there are substantial potentially available water resources as a whole in Central Asia. The smallest per capita amount of water is represented by Uzbekistan with $1870 \mathrm{~m}^{3}$ /capita and year. In general, an amount of less than $3000 \mathrm{~m}^{3}$ /capita and year may be regarded as economic water scarcity and less than $1000 \mathrm{~m}^{3} /$ capita and year as physical water scarcity [26]. According to this criterion, only Uzbekistan falls below the threshold for economic water scarcity. Most part of the surface water in Table 1 can be regarded as annually renewable water. However, it must be remembered that there is a great spatial and temporal variability of surface water. Groundwater as well, especially deeper groundwater, will not be replenished as quickly as the surface water. As seen from the table, especially Uzbekistan and Turkmenistan are dependent on water sources located outside of the country borders. This makes them more vulnerable in case of political conflict and hydropolitical issues. 
Table 1. Totally renewable water resources in Central Asian countries (surface and groundwater, after [23-25]).

\begin{tabular}{ccccc}
\hline Country & $\begin{array}{c}\text { Total Renewable Water } \\
\text { Resources (km }{ }^{3} / \text { Year; } \\
\text { within Brackets is Given } \\
\text { Share of Outside Sources) }\end{array}$ & $\begin{array}{c}\text { Total Renewable } \\
\text { Water Resources } \\
\left(\mathbf{m}^{3} / \text { Capita and Year) }\right.\end{array}$ & $\begin{array}{c}\text { Average } \\
\text { Precipitation } \\
\text { (mm/Year) }\end{array}$ & $\begin{array}{c}\text { Main Agricultural } \\
\text { Production }\end{array}$ \\
\hline Kazakhstan & $117(34)$ & 6490 & 250 & Wheat, livestock \\
Kyrgyzstan & $58(0)$ & 8480 & 530 & Livestock \\
Tajikistan & $99(16)$ & 13,500 & 690 & Cotton, wheat \\
Turkmenistan & $25(23)$ & 4090 & 160 & Fruit, vegetables \\
Uzbekistan & $59(34)$ & 1870 & 265 & Cotton, wheat, fruit \\
\hline
\end{tabular}

During the last decades of the 20th century, Central Asia suffered an enormous ecological crisis. The Aral Sea, the fourth largest lake in the world, started to dry up [27]. The reason for this was the doubling of irrigated agricultural area from 4.3 to 8.2 million ha. Due to the changed ecology, several hundred thousand square kilometers with a population of several million have been damaged [28].

As seen from the above, the Central Asian states are not water scarce in terms of total water supply per capita. The uneven distribution in space and time in combination with excessive and often uncontrolled withdrawal for irrigation, however, create water scarcity especially in areas to the south. These problems can only be solved at the international level and involving integrated water resources management. This, however, requires a political will and the involvement of all stakeholders, including an environmentally aware public.

\section{Threats to Water Quality}

\subsection{Human Waste}

Just before the Soviet Union collapse, about $70 \%$ of all cities and $20 \%$ of all villages had their own wastewater collection systems [23]. Wastewater treatment plants were usually designed with mechanical and biological treatment. When the Soviet State collapsed in 1991, the majority of wastewater treatment plants halted their operation. During the following period, lack of investment and maintenance resulted in serious degradation of the majority of sewage treatment plants. Still, most wastewater treatment plants do not operate efficiently. Their present technical standard is insufficient due to lack of equipment and spare parts, chemicals, and trained personnel [23]. Almost everywhere, biological treatment stages are not functioning efficiently. Mechanical treatment is only operating at a few city wastewater treatment plants.

According to Unicef and the MDG (Millennium Development Goals) the portion of the 2015 population who gained access to improved sanitation since 1990 for Caucasus and Central Asia was $24 \%$ [29]. All Central Asian countries except for Turkmenistan (no data) achieved $93 \%-100 \%$ improved sanitation. Reviews indicate that improved sanitation can reduce diarrhoeal diseases by $32 \%-37 \%$ [30-32]. However, improved sanitation needs to be combined with good operation and maintenance of water supply systems. Worn-out water pipe-lines are often the reason of deteriorated potable water quality and higher incidence of intestinal infections.

One gram of fresh faeces from an infected person can contain $10^{8}$ viral pathogens, $10^{8}$ bacterial pathogens, $10^{4}$ protozoan cysts, and $10^{4}$ helminth eggs [33,34]. The lack of sanitation, as well as occurrence of polluted water, cause different consequences in the health of the population [35]. Drinking water provided by old water pipes can be the cause of acute gastrointestinal illnesses such as typhoid, dysentery, and cases of viral Hepatitis A [35-37]. Diarrhoeal disease accounts for an estimated $4.1 \%$ of the total DALY (disability-adjusted life year) global burden of disease. It has been estimated that $88 \%$ of that burden are attributable to unsafe water supply, sanitation, and hygiene according to World Health Organization [28]. In the harsh climate of Central Asia, rural villagers often obtain water from shallow wells $[38,39]$. These wells are typically located near the house and the 
outdoor toilet. The prevalence of Heliobacter pylori infections is inversely related to living standard and sanitary practice [40,41]. H. pylori infection is linked with gastritis and associated diseases such as peptic ulcer, gastric adenocarcinoma, and primary gastric lymphoma [36]. In Kazakhstan, the morbidity and mortality associated with gastrointestinal diseases are high and gastric cancer is the second largest cause of cancer death [38,42]. Results by Nurgalieva et al. [38] suggest that transmission of $H$. pylori can be water borne, related to poor sanitary practices, or both.

\subsection{Agriculture}

Central Asia has been one of the world's fastest growing regions since the end of the 1990s [18]. Thus, the area has shown a strong development potential. The reasons for this are natural resources such as oil, gas, and gold together with cotton and agricultural production combined with acceptable infrastructure and human capital. The added value of agriculture to the GDP is about $10 \%$ for the Central Asian region (2010) [18]. It generally ranged from 5\% in Kazakhstan to about 21\% in Kyrgyzstan and Tajikistan. On average, about 30\% of the economically active population are engaged in farming (ranging from $14 \%$ in Kazakhstan to $29 \%$ in Turkmenistan) [18]. Cultivated area per person economically active in agriculture varies from 1.1 to $1.7 \mathrm{ha} /$ person in Tajikistan and Uzbekistan respectively, 2.7 ha/person in Kyrgyzstan and Turkmenistan to almost 20 ha/person in Kazakhstan [18]. This gives an average for the region of $3.3 \mathrm{ha} /$ person.

Requirements to maximise irrigated agriculture during the Soviet era resulted in a general degradation of water resources. After independence, most countries in the region adopted national policies regarding water supply and sanitation. Still, about $90 \%$ of the total water supply are used for irrigation [23]. Intensified irrigation increases the water pollution by chemicals used in agriculture. Increased agricultural production leads to an increased usage of mineral fertilizers and chemicals protecting plants against pests, weed, and diseases. As a result, many chemical substances, pesticides, and herbicides are discharged to the environment. Some of the substances such as DDT are bio-resistant and have a reported half-life of about 15 years in soil.

The drying up of the Aral Sea and the decrease of the water surface area combined with increasing contamination levels in the remaining water bodies, constitute a threat for environment and humans [27]. Irrigation return contains salts, fertilizers, pesticides, herbicides, and cotton defoliants [43]. However, at present significant efforts are being made to restore wetlands, improve habitat conditions, and reduce pollution in the Aral Sea region [44]. Even so, I.V. Severskiy [2] notes that salinization and pollution problems are increasing due to irrational land and water use. About $50 \%$ of the irrigated area in the Aral Sea basin are experiencing increased salinization. This has resulted in up to $50 \%$ reduction in agricultural productivity $[45,46]$. Agricultural pollution is especially affecting downstream areas of Amu Darya and Syr Darya [2]. Copper, zinc, and chromium concentrations exceed maximum permissible concentration [47]. More than 70\% of the area within the Amu Darya Basin in Uzbekistan have a water quality that is dangerous to health. More than $10 \%$ of the water are extremely dangerous [48,49].

The above clearly materializes two areas of strong concern, safe sanitation and safe management of chemical elements in agriculture. Large investments are needed to rehabilitate both water supply and sanitary systems in Central Asia. The public need to be made aware of the dangers with using open unprotected water sources and the direct benefits of paying for a safe water supply. For irrigated agriculture in the south Central Asia, wasteful irrigation techniques need to be curbed. If possible, re-use techniques of water should be developed. Alternative methods to the excessive use of herbicides and pesticides need to be established. At the same time, environmental control and management need to be put in place involving all concerned stakeholders.

\subsection{Industry}

Surface and groundwater quality in the Central Asian region, is commonly affected by agriculture, municipal wastewater as well as industry. In Kazakhstan, water sources are often classified as 
unsatisfactory [18]. Common types of water pollution is chemical, oil, manufacturing and metallurgical industry contamination. The Kazakhstan Hydrometeorology Service Bureau classified less than 30\% as clean out of 44 investigated water sources in 2002. Also, besides the common polluters such as industrial, mineral extracting and refinery enterprises, urban buildings, farms, irrigated fields, waste containers, and storage facilities for liquid and solid waste and oil products contribute to the general pollution level [18]. River water in Kyrgyzstan, however, usually displays good water quality due to that it is fed by glacial melt. Nitrate, organic matter content, and nutrient contents are usually low. There are a few cases of water pollution from storage facilities and use of fertilizers and chemicals, industrial waste, non-compliance of the sanitary code, improper conditions for sewerage systems, cattle breeding, and industrial effluent. The water source for drinking water is usually groundwater. Nuclear tailing dumps, however, are a serious problem in Kyrgyzstan. Also in Tajikistan, water supply is in general satisfactory, except for a few lakes and groundwater sources. In Turkmenistan, however, river water and drainage networks are often polluted. The river water repeatedly contains high concentrations of salts and pesticides both from domestic sources and upstream international basins. This is especially the case for the Aral Sea Basin where the human pressure on surface water is high. In Uzbekistan, some rivers that receive discharge of sewage and municipal wastewater display high pollution levels. Pollution from petroleum industry may reach 0.4 to $8.2 \mathrm{MAC}$ (maximum allowable concentration), phenols pollution may reach 6 MAC, nitrates 3.7 MAC, and heavy metals $11 \mathrm{MAC}$ [18]. This also threatens the groundwater.

\section{Access to Safe Water Drinking Water}

\subsection{Drinking Water Supply}

In general, during the last 10-15 years of independence, the quality of the water supply services has dramatically deteriorated [23]. The main cause for this deterioration is the marked reduction in public spending due to the general economic recession. In 2010 , about $74 \%$ of the total population in Central Asia, 94\% of the urban, and $64 \%$ of the rural population had access to improved drinking water sources (Table 2). About 7.5 million in Uzbekistan, 4.8 million people in Tajikistan, and 2 million in Kyrgyzstan lack proper access to clean drinking water [22,50,51]. The World Bank points at the Kyrgyzstan's worsening health indicators are caused by poor sanitation and hygiene [52]. However, the World Health Organisation (WHO) notes that improved access to water in Central Asia has occurred since 2011 [53]. WHO [53] summarized problems with safe access to drinking water in Kazakhstan but this also holds for most of Central Asia [54]:

1 Degradation of the water supply infrastructure that is $80 \%-100 \%$ in some cases leading to frequent interruption of water supply and massive losses of water;

2 Unclear relationships between willingness to pay for water supply service and installment of meters in relation to perceived gains;

3 Despite measures aiming at providing public access to fresh water it is still unavailable for a majority of the rural population.

Table 2. Access to drinking water and sanitation in Central Asia (adapted from [23]).

\begin{tabular}{ccccc}
\hline & \multicolumn{2}{c}{ Access to Water for Population (\%) } & \multicolumn{2}{c}{ Coverage of Sanitation System (\%) } \\
\cline { 2 - 5 } & Urban & Rural & Urban & Rural \\
\hline Kazakhstan & 78 & $>35$ & 84 & 10 \\
Kyrgyzstan & 82 & 58 & 68 & 28 \\
Tajikistan & 93 & 49 & 20 & 5 \\
Turkmenistan & 85 & 42 & 62 & 2 \\
Uzbekistan & 90 & 71 & 85 & 40 \\
\hline
\end{tabular}


On the positive side, Roberts et al. [55] found that there have been improvements in access to piped water in Central Asia between 2001 and 2010. However, the authors state that still significant gaps remain. This is particularly true for the rural and poor households. There is a need for sustained investment in basic infrastructure for piped water in the region that ensures poorer and rural populations to benefit. In Kazakhstan, $78 \%$ of the urban population and $>35 \%$ of the rural population have access to a varying degree of safe drinking water [23] (Table 2). In general, urban areas are supplied rather well with both drinking water and safe sanitation. Rural areas at large distances from central water supplies and piped sewage systems face serious difficulties. In Kyrgyzstan, the same figures are $82 \%$ and $58 \%$, respectively. The wear-and-tear of the rural water supply system is $>40 \%$ that often means contamination of microbes and chemicals [23]. According to Global Water Partnership, Central Asia and Caucasus [23], a population in excess of 600,000 people in Kyrgyzstan does not have access to safe sources of drinking water and take water from irrigation canals, ditches, and rivers. In Tajikistan, $93 \%$ of the urban population and less than $49 \%$ of the rural population have access to piped drinking water. About $80 \%$ of the rural population use water that does conform to hygienic standards [23]. In Turkmenistan about $85 \%$ and $42 \%$, in urban and rural areas, respectively, have access to piped water. The same figures for Uzbekistan are about $90 \%$ and $71 \%$. According to the above, it is clear that especially the rural and poor households do not have access to safe water supply. The situation is similar all over Central Asia.

\subsection{Treatment of Drinking Water}

Inferior drinking water quality contributes to the general health problems of the population [55-65]. The low level of access to high-quality drinking water is only one of the major problems in Central Asian countries. Ageing and lack of maintenance of water pipeline networks cause emergency conditions, in which people have to use water from other, mostly untreated sources of water. Other factors also play a major role such as pollution of water supply sources, discharge from industry and agriculture, and secondary pollution of drinking water by bacterial activity caused by deterioration of the anticorrosion coating of pipe surfaces $[31,66]$.

The majority of existing drinking water treatment plants and water supply systems in Central Asia were built during the period 1950-1980. The construction philosophy was to build systems that needed low capital investment and small cost for process equipment but considerably high operational costs [23]. The main emphasis was to exploit new water supply sources in terms of pumping stations, water treatment facilities, and maximum flow capacity in main water pipes. Efficient development of water distribution systems, their zoning and rational water use, metering and administrational issues were considered to be outside of the operators' scope of activities [23]. The main problem of today is often to supply rural areas with safe water in a degraded pipe system. In many cases disinfection by chlorine is the only method used. Sometimes no disinfection is taking place. However, even chlorination will not be satisfactory due to leaks and contamination during flooding. In order to modernize the water supply system that on average is older than 35 years over vast areas such as, e.g., the Kazakhstan territory, huge investments are necessary. A possible strategy would be to also invest in locally adapted small-scale water supply and sanitation systems.

\section{Health Impacts}

K. Frenken [18] investigated health effects from water-related problems in Turkmenistan, Kyrgyzstan, and Uzbekistan. The authors summarized that, although no information is available, similar problems may be present in also the other countries of Central Asia. Major factors affecting the spread of water-related diseases were identified as:

1 Use of untreated wastewater to meet water shortage;

2 Lack of infrastructure, especially related to wastewater treatment and discharge;

3 Lack of health awareness and proper handling of polluted water; and

4 Lack of regulations related to the protection of the environment and public health. 
In Kyrgyzstan, 122,800 inhabitants were reported to be affected by water-related diseases (2005). In Turkmenistan, inhabitants affected by water-related diseases were estimated to be 12,295 (2004). Out of these, 7955 were intestinal infections, 22 were typhoid, and 4318 were virus hepatitis. An outbreak of malaria with 137 cases occurred in 1998. Since then malaria is reported as eliminated. In Uzbekistan, agricultural productivity is reduced due to land and water salinization. The population in these areas suffers from high levels of anaemia, together with growing levels of tuberculosis. Children are affected by liver, kidney and respiratory diseases, micronutrient deficiencies, cancer, immunological problems, and birth defects. In Karakalpakstan $40 \%$ of the rural population depend on small subsistence plots for their livings. These plots are negatively affected by water scarcity and pollution. The situation worsened during 2001-2002 in Karakalpakstan and Khorezm from a drought period and water shortage negatively impacted domestic and personal hygiene [18]. During this period the poor rural people were exposed to a higher risk for water-related diseases such as typhoid, diarrhoea, and worm infections. The government has made progress, however, still only $54 \%$ of the urban and $3 \%$ of the rural population have access to adequate sewage systems.

\subsection{Non-Microbiological Contaminants}

Release of contaminants from industry and agricultural areas can spread pollutants to extensive downstream areas. Raised concentrations of organochlorine pesticides and toxic metals such as arsenic have been found in human blood, milk, hair, and urine of the exposed population living in the Aral Sea Drainage Basin [67-70]. The exposed population is experiencing increasing maternal and infant mortality, delay in growth and puberty of children, liver and digestive problems, allergies, and diseases related to occurring bacteria in water $[67,71,72]$. In the area, only $20 \%-30 \%$ of the rural population have access to piped water and $25 \%$ use water from irrigation channels as their main drinking water source [73]. Also other elements have been found in the drainage basin's surface and groundwater with higher concentrations as compared to the World Health Organization (WHO) maximum recommended contents such as nitrogen species, copper, lead, chromium, and uranium $[67,74-77]$. The type of health effects depends on type of contaminant and exposure time [59,67,78]. Organic pollutants such as DDT, DDD, and DDE are used in controlling weeds and pests in the Aral Sea Drainage Basin and probably elsewhere in Central Asia. Törnqvist et al. [68] found that the surface water constituents copper, arsenic, nitrite, and DDT in Mejdurechye reservoir are above recommended maximum concentrations by WHO and represent cumulative health hazards. Even more alarming results were that groundwater was overall associated with much higher health risks as compared to surface water. Switching from surface water to groundwater, e.g., during drought periods, is therefore not encompassing better quality water.

\subsection{Microbiological Elements}

As mentioned above, contact between inappropriate sanitary facilities and drinking water supplies can result in serious infection risks. Matthys et al. [79] investigated the overall prevalence of infection with helminths and pathogenic intestinal protozoa in school children for a rural area in Tajikistan. Helminthiasis and intestinal protozoa infections are of considerable public health importance in Tajikistan and elsewhere in Central Asia [80,81]. The overall prevalence of infection with helminths and pathogenic intestinal protozoa was found to be $32 \%$ and $47 \%$, respectively. There was pronounced spatial heterogeneity. The most common helminth species were Hymenolepis nana $(26 \%)$, whereas the prevalence of Ascaris lumbricoides, hookworm, and Enterobius vermicularis was below 5\%. The prevalence of pathogenic intestinal protozoa, namely Giardia intestinalis and Entamoeba histolytica/ E. dispar was both $26 \%$. Almost half of the households took drinking water from open water sources, such as irrigation channels, rivers, and unprotected wells. The households used sanitary facilities such as pit latrines, mostly private, and sometimes shared with neighbours. The use of public tap/standpipe as a source of drinking water supply proved to be a protective factor against $G$. intestinalis infection. Protected spring water also reduced the risk of infection with E. histolytica/E. dispar and H. nana. 
Climate change is likely to have less effects on human vulnerability as compared to changes in land use and inefficient water management [82]. However, climate change is likely to increase the region's vulnerability through the water supply and thereby water-borne and vector-borne infections. The rapid economic decline after the Soviet State collapse in 1991 brought back epidemic typhus, tuberculosis, diphtheria, meningitis as well as other infectious diseases to Central Asia [83,84]. Another example is malaria through the Plasmodium falciparum that was almost eradicated in Soviet Union by the end of the 50ies through campaigns of insecticides, anti-malarial therapy, land reclamation, and water management. However, in the 1990s malaria was back in Uzbekistan, Kyrgyzstan, Turkmenistan, and Tajikistan [85]. Climate change resulting in increase in winter temperature and changing precipitation patterns may increase the region's vulnerability by creating more favorable conditions for vectors and parasites. In addition, infectious diseases spreading through oral-fecal mechanisms, e.g., typhoid, paratyphoid, salmonella, dysentery, amebiasis, and helminthiasis, are all associated to warm climate [82].

\section{Conclusions and Discussion}

The Central Asian countries share many common problems and unaddressed tasks in health-related water supply and sanitation [23]. The degradation rate of the water supply systems and sewage treatment plants are high. This leads to potentially high water loss rates and inadequate accessibility to safe water supply which is a specific problem for rural areas. Low tariffs in combination with absent metering and low collection rates for water fees mean that operation and maintenance costs for basic services of water supply and sanitation are not covered. The human resource base for the water supply and sanitation systems needs to be better trained and capacity building is needed for the governance. Large distances between remote and sparsely populated villages in rural areas means that alternative systems may be needed. Such systems may be constituted by efficient and small-scale water supply and sanitation systems.

The environmental codex and regulations need to be implemented and strengthened. Ecological expertise needs to be supplied to industrial as well as agricultural activities in order to ensure appropriate environmental monitoring of pollutants. The polluter pay principle needs to be introduced and legislated [31].

Legislative and controlling environmental authorities need be strengthened and made more efficient. There is a general lack of integration between ministries, nongovernmental organizations, and the general public. By implementing integrated water resources management all ministries for environmental protection, agriculture, water resources, health, local governments, municipal authorities, nongovernmental organizations, and representatives for industry can jointly solve water and environmental problems, create national action plans, as well as plans on the regional and local levels.

Ecological thinking needs to be stressed in education. Also, the general awareness regarding environment and detrimental effects of human and industrial waste needs to be strengthened.

Author Contributions: The first four authors planned and wrote the first version of the paper. The other authors contributed in an equal manner to the paper by adding comments and writing parts of the final paper.

Conflicts of Interest: The authors declare no conflict of interest.

\section{References}

1. Cowan, P.J. Geographic usage of the terms Middle Asia and Central Asia. J. Arid Environ. 2007, 62, 359-363. [CrossRef]

2. Severskiy, I.V. Water-related problems of Central Asia: Some results of the (GIWA) international water assessment program. Ambio 2004, 33, 52-62. [CrossRef] [PubMed]

3. Tussupova, K.; Berndtsson, R.; Bramryd, T.; Beisenova, R. Investigating willingness to pay to improve water supply services: Application of contingent valuation method. Water 2015, 7, 3024-3039. [CrossRef] 
4. Siegfried, T.; Bernauer, T.; Guiennet, R.; Sellars, S.; Robertson, A.W.; Mankin, J.; Bauer-Gottwein, P.; Yakovlev, A. Will climate change exacerbate stress in Central Asia? Clim. Chang. 2012, 112, 881-899. [CrossRef]

5. Dukhovny, V.A. Water economy problems of the Aral Sea basin countries: Ten years of cooperation and perspectives. Improv. Water Econ. 2002, 1, 66-70. (In Russian)

6. Kipshakbayev, N.K.; Sokolov, V.I. Water resources of the Aral Sea basin-Formation, distribution, usage. In Water Resources of Central Asia; ICWC Press: Tashkent, Uzbekistan, 2002; pp. 63-67. (In Russian)

7. Kamalov, T.K. Water crisis of southern Priaralje-contemporary status and perspectives. In Water Resources of Central Asia; ICWC Press: Tashkent, Uzbekistan, 2002; pp. 74-78. (In Russian)

8. Ramazanov, A.M. Water resources of Kazakhstan: Problems and perspectives for usage. Improv. Water Econ. 2002, 1, 10-15. (In Russian)

9. Ryabtsev, A.D.; Akhmetov, S.K. Kazakhstan water resources: Problems and prospects of using. Hydrometeorol. Ecol. 2002, 1, 51-73. (In Russian)

10. Lack, T. Water and health in Europe. BMJ 1999, 318, 1678-1682. [CrossRef] [PubMed]

11. Adany, R.; Villerusa, A.; Bislimovska, J.; Kulzhanov, M. Public health education in Central and Eastern Europe, and Central Asia. Public Health Rev. 2011, 33, 105-133.

12. McKee, M.; White, M.; Bojan, F.; Osrbye, T. Development of public health training in Hungary-An exercise in international co-operation. J. Public Health Med. 1995, 17, 438-444. [PubMed]

13. Adeyi, O.; Chellarai, G.; Goldstein, E.; Preker, A.; Ringold, D. Health status during the transition in Central and Eastern Europe: development in reverse? Health Policy Plan. 1997, 12, 132-145. [CrossRef] [PubMed]

14. Oreskovic, S. New priorities for health sector reform in Central and Eastern Europe. Croat. Med. J. 1998, 39, 225-233. [PubMed]

15. Kulzhanov, M.; Rechel, B. Kazakhstan: Health system review. European Observatory on Health Systems and Policies. Health Syst. Trans. 2007, 9, 158.

16. Islamov, U.; Khamzayeva, A.; Maksudov, F.; Maksudova, D.; Rahimov, S.; Sakiev, B. Water Resources Management in Central Asia: Regional and International Issues at Stake; Serie: Asia, Número 25; Fundació CIDOB: Barcelona, Spain, 2009.

17. O'Hara, S.L. Central Asia's water resources: contemporary and future management issues. Int. J. Water Resour. Dev. 2000, 16, 423-441. [CrossRef]

18. FAO Land and Water Division, Food and Agriculture Organization of the United Nations. Irrigation in Central Asia in Figures, AQUASTAT Survey-2012; FAO Water Reports 39; Frenken, K., Ed.; FAO: Rome, Italy, 2013.

19. CAWaterInfo. The Aral Sea Basin. 2011. Available online: http://www.cawater-info.net/aral/index_e.htm (accessed on 6 April 2016).

20. Xu, L.; Zhou, H.; Du, L.; Yao, H.; Wang, H. Precipitation trends and variability from 1950 to 2000 in arid lands of Central Asia. J. Arid Land 2015, 7, 514-526. [CrossRef]

21. Yin, Z.Y.; Wang, H.; Liu, X. A comparative study on precipitation climatology and interannual variability in the lower midlatitude East Asia and Central Asia. J. Clim. 2014, 27, 7830-7848. [CrossRef]

22. International Crisis Group. Water Pressures in Central Asia; Europe and Central Asia Report No. 233; International Crisis Group: Brussels, Belgium, 2014; p. 35.

23. Global Water Partnership, Central Asia and Caucasus. Regional Review, Water Supply and Sanitation in the Countries of Central Asia and Southern Caucasus. Available online: http://www.gwp.org/global/ activities/news/wssobzor_eng_aug2009.pdf (accessed on 23 May 2016).

24. FAO. Review of World Water Resources by Country; Water Report 23; FAO: Rome, Italy, 2003; p. 111.

25. UNDP. Water Resources of Kazakhstan in New Millennium; Review of the UNDP; UNDP: Almaty, Kazakhstan, $2004 ;$ p. 114.

26. Brown, A.; Matlock, M.D. A Review of Water Scarcity Indices and Methodologies; Food, Beverage \& Agriculture, The Sustainability Consortium, University of Arkansas, White Paper 106; The Sustainability Consortium: Fayetteville, AR, USA, 2011; p. 19.

27. Micklin, P. The Aral Sea disaster. Annu. Rev. Earth Planet. Sci. 2007, 35, 47-72. [CrossRef]

28. Khvorog, G.V., Ed.; Ecological Map of the Near Aral Region; G.V. Khvorog: Alma-Ata, Kazakhstan, 1992. (In Russian)

29. Unicef. Progress on Sanitation and Drinking Water-2015 Update and MDG Assessment; WHO Library Cataloguing-in-Publication Data; WHO: Geneva, Switzerland, 2015. 
30. Fewtrell, L.; Kaufmann, R.B.; Kay, D.; Enanoria, W.; Haller, L.; Colford, J.M., Jr. Water, sanitation, and hygiene interventions to reduce diarrhoea in less developed countries: A systematic review and meta-analysis. Lancet Infect. Dis. 2005, 5, 42-52. [CrossRef]

31. Esrey, S.A., Gough, J., Rapaport, D., Sawyer, R., Simpson-Hébert, M., Vargas, J., Winblad, U., Eds.; Ecological Sanitation; Swedish International Development Cooperation Agency: Stockholm, Sweden, 1998; p. 100.

32. Waddington, H.; Snilstveit, B. Effectiveness and sustainability of water, sanitation, and hygiene interventions in combating diarrhoea. J. Dev. Eff. 2009, 1, 295-335. [CrossRef]

33. Mara, D.; Lane, J.; Trouba, D. Sanitation and health. PLoS Med. 2010, 7, e1000363. [CrossRef] [PubMed]

34. Feachem, R.G.; Bradley, D.J.; Garelick, H.; Mara, D.D. Sanitation and Disease: Health Aspects of Wastewater and Excreta Management; John Wiley \& Sons: Chichester, UK, 1983; p. 326.

35. Tussupova, K. The Management System of the Drinking Water and Its Relation to Health in the Republic of Kazakhstan; Master of Science in Public Health, Medical and Health Science Center, University of Debrecen; University of Debrecen: Debrecen, Hungary, 2007; p. 26.

36. National Environmental Health Action Plan (Kazakhstan). Available online: http://enrin.grida.no/htmls/ aralsoe/nehap/kazakh.pdf (accessed on 12 February 2016).

37. WHO. Water Sanitation and Health. Available online: http://www.who.int/water_sanitation_health/ diseases/burden/en/index.html (accessed on 12 February 2016).

38. Nurgalieva, Z.Z.; Malaty, H.M.; Graham, D.Y.; Almuchambetova, R.; Machmudova, A.; Kapsultanova, D.; Osato, M.S.; Hollinger, F.B.; Zhangabylov, A. Helicobacter pylori infection in Kazakhstan: Effect of water source and household hygiene. Am. J. Trop. Med. Hyg. 2002, 67, 201-206. [PubMed]

39. Snegireva, M.S. Detection of Quantitative Connections between Biological Impurity of Potable Water and Morbidity of the Population of Republic of Kazakhstan by Intestinal Taints; M.S. Snegireva: Almaty, Kazakhstan, 1999; pp. 3-28.

40. Breuer, T.; Malaty, H.M.; Graham, D.Y. The Epidemiology of H. pylori-Associated gastroduodenal diseases. In The Immunobiology of H. Pylori: From Pathogenesis to Prevention; Ernst, P.B., Michetti, P., Smith, P.D., Eds.; Lippincott-Raven: Philadelphia, PA, USA, 1997; pp. 1-14.

41. Shiotani, A.; Nurgalieva, Z.Z.; Yamaoka, Y.; Graham, D.Y. Helicobacter pylori. Med. Clin. N. Am. 2000, 84, 1125-1136. [CrossRef]

42. Abdrachmanov, Z.N.; Pozdnyakova, A.P.; Filippenko, V.I.; Tashenova, K.O. Indexes of Oncological Services of the Republic of Kazakhstan for 1998: Statistical Data; Prints-S: Almaty, Kazakhstan, 1999; pp. 3-73.

43. Micklin, P.P. The water management crisis in Soviet Central Asia. In The Carl Beck Papers in Russian and East European; Stud. No. 905; Pittsburgh: Cent. Russ./East Eur. Stud.; University of Pittsburgh: Pittsburgh, PA, USA, 1991.

44. Chub, V.Y. Climate Change and Its Influence on the Natural Resource Potential of the Republic of Uzbekistan; Glavgidromet: Tashkent, Uzbekistan, 2002. (In Russian)

45. Abdulkasimov, H.P.; Alibekova, A.V.; Vakhabov, A.V. Desertification Problems in Central Asia and Its Regional Strategic Development; Abstracts, NATO Advanced Research Workshop; NATO: Samarkand, Uzbekistan; 11-14; June; 2003. (In Russian)

46. Reteyum, A.Y. The factors and results of desertification of central Asia. In Desertification Problems in Central Asia and Its Regional Strategic Development; Abstracts, NATO Advanced Research Workshop; NATO: Samarkand, Uzbekistan; 11-14; June; 2003. (In Russian)

47. Chembarisov, E.I.; Lesnik, T.V. To the preserve of surface waters of Central Asia. In Issue of SANIGMI "Fresh Water"; Denisov, Y.M., Ed.; SANIGMI Press Tashkent: Tashkent, Uzbekistan, 1995; pp. 64-71. (In Russian)

48. Chembarisov, E.I.; Lesnik, T.V.; Ranneva, I.V. Contemporary River's water quality of Uzbekistan. In Water and Sustainable Development of Central Asia; Tuzova, T.V., Ed.; Materials of the projects "Regional cooperation on the usage of water and power resources in Central Asia (1998)" and "Hydroecological problems and sustainable development of Central Asia"; American University in Kyrgyzstan: Bishkek, Kyrgyzstan, 2001; pp. 39-41. (In Russian)

49. Zharkov, V.V.; Zharkov, D.V. Hydrochemical composition of waters of the Karakum-river. Probl. Desert Dev. 2002, 4, 66-71. (In Russian)

50. Normand, O. Regional rural water supply and sanitation project Ferghana Valley. In Proceedings of the 6th International Conference on World Water Forum-Cooperative Actions for Water Security, Tashkent, Uzbekistan, 12-13 May 2011. 
51. Isman, A.; Toktaliev, M. Kyrgyzstan without Water. In Radio Free Europe/RadioAzattyk; 13; December; 2012.

52. World Bank. Implementation Completion and Results on a Credit in the Amount of SDR 12 Million (US\$15 Million Equivalent) to the Kyrgyz Republic for a Rural Water Supply and Sanitation Project; Report IDA-35790; World Bank: Washington, DC, USA; 15; May; 2009.

53. WHO. Improved Water Source, Rural (\% of Rural Population with Access). Available online: http://data. worldbank.org/indicator/SH.H2O.SAFE.RU.ZS (accessed on 26 February 2016).

54. Syrlybayeva, B.R. Fresh Drinking Water Supply for Population of Kazakhstan. Available online: http:/ / kisi.kz/en/categories/economy-and-energy/posts/fresh-drinking-water-supply-for-populationof-kazakhsta372 (accessed on 12 February 2016).

55. Roberts, B.; Stickley, A.; Gasparishvili, A.; Haerpfer, C.; McKee, M. Changes in household access to water in countries of the former Soviet Union. J. Public Health 2012, 34, 352-359. [CrossRef] [PubMed]

56. Milibaeva, R.T. Control of the drinking water safety in Kazakhstan. In Proceedings of the 3D International Exhibition and Conference "Su Arnasy 2007", Astana, Kazakhstan, 23-25 May 2007.

57. Bain, R.; Cronk, R.; Wright, J.; Yang, H.; Slaymaker, T.; Bartram, J. Fecal contamination of drinking-water in low- and middle-income countries: A systematic review and meta-analysis. PLoS Med. 2014, 11, e1001644. [CrossRef] [PubMed]

58. White, G.F.; Bradley, D.J.; White, A.U. Drawers of Water: Domestic Water Use in East Africa; The University of Chicago Press: Chicago, IL, USA, 1972.

59. WHO. Guidelines for Drinking-Water Quality; World Health Organization: Geneva, Switzerland, 2011.

60. Esrey, S.A.; Feachem, R.G.; Hughes, J.M. Interventions for the control of diarrhoeal diseases among young children: Improving water supplies and excreta disposal facilities. Bull. World Health Organ. 1985, 63, 757-772. [PubMed]

61. Fewtrell, L.; Colford, J.M., Jr. Water, sanitation and hygiene in developing countries: interventions and diarrhoea-A review. Water Sci. Technol. 2005, 52, 133-142. [PubMed]

62. Clasen, T.; Roberts, I.; Rabie, T.; Schmidt, W.; Cairncross, S. Interventions to improve water quality for preventing diarrhoea. Cochrane Database Syst. Rev. 2006, 19, CD004794.

63. Cairncross, S.; Hunt, C.; Boisson, S.; Bostoen, K.; Curtis, V.; Fung, I.C.H.; Schmidt, W.-P. Water, sanitation and hygiene for the prevention of diarrhoea. Int. J. Epidemiol. 2010, 39, i193-i205. [CrossRef] [PubMed]

64. Ligon, G.C. Waterborne Disease Outbreaks: A Systematic Review of the Health Effects of Drinking Water System Failures; Chapel Hill (North Carolina), University of North Carolina at Chapel Hill: Chapel Hill, NC, USA, 2012.

65. Craun, G.F.; Brunkard, J.M.; Yoder, J.S.; Roberts, V.A.; Carpenter, J.; Wade, T.; Calderon, R.L.; Roberts, J.M.; Beach, M.J.; Roy, S.L. Causes of outbreaks associated with drinking water in the United States from 1971 to 2006. Clin. Microbiol. Rev. 2010, 23, 507-528. [CrossRef] [PubMed]

66. UNDP. Water Resources of Kazakhstan in the New Millennium; UNDP Kazakhstan, A Series of UNDP Publication in Kazakhstan, \# UNDPKAZ 07; UNDP: Almaty, Kazakhstan, 2004.

67. Törnqvist, R.; Jarsjö, J.; Karimov, B. Health risks from large-scale water pollution: Trends in Central Asia. Environ. Internsh. 2011, 37, 435-442. [CrossRef] [PubMed]

68. Atanyiazova, O.A.; Baumann, R.A.; Liem, A.K.D.; Mukhopadhyay, U.A.; Vogelaar, E.F.; Boersma, E.R. Levels of certain metals, organochlorine pesticides and dioxins in cord blood, maternal blood, human milk and some commonly used nutrients in the surroundings of the Aral Sea (Karakalpakstan, Republic of Uzbekistan). Acta Paediatr. 2001, 90, 801-808. [CrossRef]

69. Erdinger, L.; Eckl, P.; Ingel, F.; Khussainova, S.; Utegenova, E.; Mann, V.; Gabrio, T. The Aral Sea disaster-human biomonitoring of $\mathrm{Hg}$, As, $\mathrm{HCB}, \mathrm{DDE}$, and PCBs in children living in Aralsk and Akchi, Kazakhstan. Int. J. Hyg. Environ. Health 2004, 207, 541-547. [CrossRef] [PubMed]

70. Jensen, S.; Mazhitova, Z.; Zetterström, R. Environmental pollution and child health in the Aral Sea region in Kazakhstan. Sci. Total Environ. 1997, 206, 187-193. [CrossRef]

71. Elpiner, L.I. Public health in the Aral Sea coastal region and the dynamics of changes in the ecological situation. In Creeping Environmental Problems and Sustainable Development in the Aral Sea Basin; Glantz, M., Ed.; Cambridge University Press: Cambridge, UK, 1999; pp. 128-156.

72. Zetterström, R. Child health and environmental pollution in the Aral Sea region in Kazakhstan. Acta Paediatr. Suppl. 1999, 88, 49-54. [CrossRef] [PubMed]

73. Small, I.; Falzon, D.; van der Meer, J.B.; Ford, N. Safe water for the Aral Sea Area: Could it get any worse? Eur. J. Public Health 2003, 13, 87-89. [CrossRef] [PubMed] 
74. Crosa, G.; Froebrich, J.; Nikolayenko, V.; Stefani, F.; Galli, P.; Calamari, D. Spatial and seasonal variations in the water quality of the Amu Darya River (Central Asia). Water Res. 2006, 40, 2237-2245. [CrossRef] [PubMed]

75. Froebrich, J.; Ikramova, M.; Razakov, R. Improved groundwater management strategies at the Amu Darya River. In Groundwater and Ecosystems; Baba, A., Howard, K.W.F., Gunduz, O., Eds.; Springer: Dordrecht, The Netherlands, 2006; pp. 153-165.

76. Kawabata, Y.; Yamamoto, M.; Aparin, V.; Ko, S.; Shiraishi, K.; Nagai, M. Uranium pollution of water in the western part of Uzbekistan. J. Radioanal. Nucl. Chem. 2006, 270, 137-141. [CrossRef]

77. Friedrich, J. Uranium contamination of the Aral Sea. J. Mar. Syst. 2009, 76, 322-335. [CrossRef]

78. Howd, R.A.; Fan, A.M. Risk Assessment for Chemicals in Drinking Water; John Wiley \& Sons, Inc.: Hoboken, NJ, USA, 2008.

79. Matthys, B.; Bobieva, M.; Karimova, G.; Mengliboeva, Z.; Jean-Richard, V.; Hoimnazarova, M.; Kurbonova, M.; Lohourignon, L.K.; Utzinger, J.; Wyss, K. Prevalence and risk factors of helminths and intestinal protozoa infections among children from primary schools in western Tajikistan. Parasites Vectors 2011, 4, 195. [CrossRef] [PubMed]

80. United Nations Development Programme Tajikistan, Republic of Tajikistan. Progress toward the Millennium Development Goals (Tajikistan 2003); United Nations Development Programme: Dushanbe, Tajikistan, 2003.

81. Steinmann, P.; Usubalieva, J.; Imanalieva, C.; Minbaeva, G.; Stefiuk, K.; Jeandron, A.; Utzinger, J. Rapid appraisal of human intestinal helminth infections among schoolchildren in Osh Oblast, Kyrgyzstan. Acta Trop. 2010, 116, 178-184. [CrossRef] [PubMed]

82. Lioubimtseva, E.; Henebry, G.M. Climate and environmental change in arid Central Asia: Impacts, vulnerability, and adaptations. J. Arid Environ. 2009, 73, 963-977. [CrossRef]

83. Elpiner, L.I. A scenario of possible effect of changes in the hydrological conditions on the medical and environmental situation: On the problem of global hydroclimatic changes. Water Resour. 2003, 30, 434-444. [CrossRef]

84. Small, I.; Bunce, N. The Aral Sea disaster and the disaster of international assistance. J. Intern. Aff. 2003, 56, 11-13.

85. McMichael, A.J.; Kovats, R.S. Climate change and climate variability: Adaptations to reduce adverse health impacts. Environ. Monit. Assess. 2000, 61, 49-64. [CrossRef]

(C) 2016 by the authors; licensee MDPI, Basel, Switzerland. This article is an open access article distributed under the terms and conditions of the Creative Commons Attribution (CC-BY) license (http://creativecommons.org/licenses/by/4.0/). 